\title{
Monitoring of antibiotic residues among sheep meats at Erbil city and thermal processing effect on their remnants
}

\author{
D.A. Al-Mashhadany \\ Department of Medical Lab Science, College of Science, Knowledge University, Erbil, Kurdistan Region, Iraq \\ Email: dhary.hammed@knu.edu.iq, Tel: +9647733565479
}

(Received June 13, 2019; Accepted July 27, 2019; Available online 23 April 2020)

\begin{abstract}
The incidence of antibiotic residues in meat is considered a serious hazard to public health. This work was conducted to survey the incidence of antibiotics residues among lambs' meats and mutton in Erbil city. The effect of thermal processing on residues was also addressed. From July to December 2018, a total of 280 samples were collected from butcher shops in Erbil city and analyzed microbiologically in plates pre-inoculated with Bacillus subtilis by direct and extraction methods. The overall incidence of antibiotics residues was $10.4 \%$ and $13.2 \%$ according to direct and extraction methods respectively. The highest incidence rate was detected in December $22.2 \%$. We found that thermal processing, cooking for 45 minutes leads to the conversion of antibiotic residues into completely inactive residues against the bactericidal bacteria. In conclusion, the presence of antibiotic residue among sheep meats in the city of Erbil is high and their persistence is easily eliminated by cooking
\end{abstract}

Keywords: Antibiotic residues, Lamb meat, Mutton, Erbil, Iraq

DOI: 10.33899/ijvs.2019.125814.1161, ( ) 2020, College of Veterinary Medicine, University of Mosul.

This is an open access article under the CC BY 4.0 license (http://creativecommons.org/licenses/by/4.0/).

\section{تواجد بقايا المضادات الحيوية بين لحوم الأغنام في مدينة أربيل وتأثير المعالجة الحرارية على بقاياها ضاري عليوي المشهداني$$
\text { قسم التحليلات المرضية، كلية العلوم، جامعة نولج، أربيل، اقليم كردستان، العراق }
$$

الخلاصة

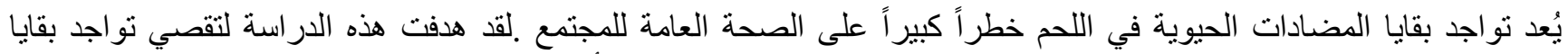

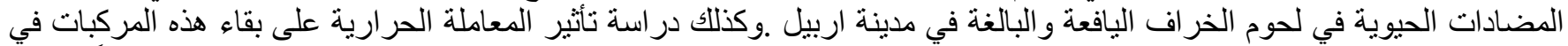

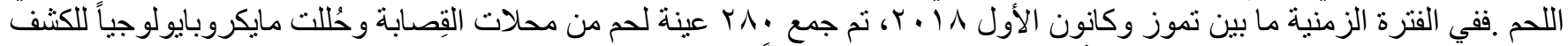

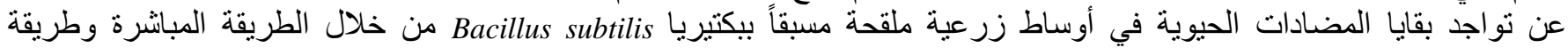

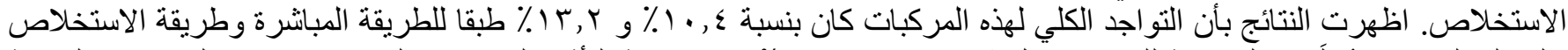

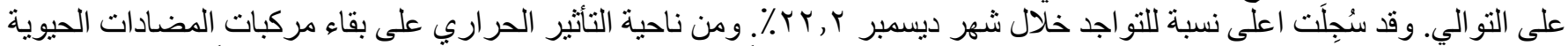

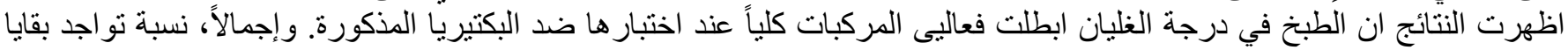

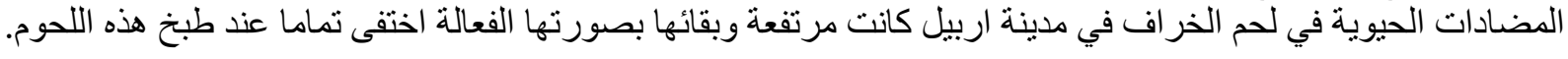

\section{Introduction}

Antibiotics, also known as antibacterial agents, are powerful secondary metabolites that have properties to fight certain infections by destroying bacterial cells or by preventing their replication. These metabolites play essential roles in veterinary, agricultural, and clinical fields. Moreover, they are extensively used in food-producing animals for prophylactic, therapeutic, and metaphylactic purposes (1-3). Red meat refers to all mammalian muscle 
meat. In gastronomy, it means any meat that is dark colored before and after cooking compared to white meat which is light in color prior to and after cooking. Sheep meat in its first year is called "lamb". This type of meat is characterized by little fat content and variation in color from a mild pink to a pale red, while the meat of an adult sheep is called "mutton". Adult sheep are typically slaughtered around two to three years of age (4-6). Antibiotic residues remain in tissues and organs of slaughtered animals and birds that have been given antibiotics previously without adherence to the withdrawal period (WP) of the antibiotic. Moreover, such residues may also be found in milk and eggs. The European Union (EU) and the Center for Veterinary Medicine (CVM), an agency under the Food and Drug Administration (FDA) in the USA, define the residues as "pharmacologically active substances (whether active principles, recipients or degradation products) and their metabolites which remain in foodstuffs obtained from animals to which the veterinary medical products (VMPs) in question has been administered" (7-9). Almost $80 \%$ of world antibiotic production is used in animal industry. In fact, some animal producers nowadays manage sub-therapeutic concentrations of antibiotics for different objectives, such as growth enhancement, impediment or decrease of disease outbreaks, enhancing digestion, acceleration of weight gain, and to rise feed conversion ratio (FCR). Therefore, residues of veterinary drugs may be present in food of animal origin even if their use is fully regulated. Indeed, such regulation is critical to ensure the proper use of veterinary drugs to protect consumers from undesirable antibiotics, and to ensure the supply of high-quality safe food products (10-12). The misuse and overuse of antibiotics in veterinary field lead to accumulation of large amounts of residues posing a serious threat to human health and economy after consuming contaminated meat tissues and organs. This problem is exacerbated by the lack or shortage of information among animal breeder about withdrawal periods of antibiotics. The incidence of antibiotic leftover in food of animal origin above the maximum residue limits (MRLs) is considered globally by different public health authorities as being illegal (13-15). Consequently, persistence of antibiotic residues in food of animal origin have been studied by different researchers in numerous countries (7,16-24). The consumption of red meat containing antibiotic residues could lead to direct toxicity, hypersensitivity; which characterized by extent of reactions ranging from mild skin rashes to lifethreatening anaphylaxis, disturbance of the normal GIT microbiota, bone marrow desolation, teratogenic and mutagenesis effects. Additionally, most of antibiotics used in animal farming can lead to emergence of antibiotic-resistant bacteria that can then be transmitted to humans through food or contact. Indeed, bacterial resistance to antibiotics is a major global health problem that has been declared by WHO as one of the major challenges facing the $21^{\text {st }}$ century $(25-$
27). Regulatory agencies and governmental authorities have established criteria regarding maximum residue limit (MRL) in various food matrices of animal origin in order to reinforce industry and food workers to control veterinary drug residues in the food chain. Nowadays, about 200 veterinary drug residues from several families, mainly with anti-parasitic, antibiotic, and anti-inflammatory behaviors are regulated in a diversity of food matrices such as milk, meat, and eggs $(7,21,28)$.

Recently, there has been a considerable increase in antibiotic residues among food of animal origin, including sheep meat. Therefore, the objectives of this study were to detect the incidence of antibiotic residues among sheep meat in Erbil city using direct and extraction methods. The association between months and incidence of antibiotic residues in sheep meat was also investigated. The effect of thermal processing on remnants was also addressed.

\section{Materials and methods}

\section{Samples collection}

A total of 280 sheep meat samples of 100 gram from carcasses of lamb and mutton (135 lamb and 145 mutton) were aseptically and randomly collected from diverse butcher shops in Erbil city, during the period from July to December 2018. The collected samples were put in separate plastic bags and transported to Pathological Analysis Department, Knowledge University, under cold condition.

In the laboratory, each sample was divided into five parts; Part 1 and 2: Used for the detection of the antibiotic residues by the direct and extraction methods. Part 3: Ten grams of each positive samples were preserved in a refrigerator at 4 ${ }^{\circ} \mathrm{C}$. After 3 days, to study the effect of chilling at $4^{\circ} \mathrm{C}$ on residues. Part 4: Ten grams of each positive samples were preserved at $-18{ }^{\circ} \mathrm{C}$ for 6 weeks. These samples used to investigate the effect of freezing at $-18{ }^{\circ} \mathrm{C}$ on residues. Part 5: Ten grams of each positive samples were used to study the effect of thermal processing (cooking) at $100{ }^{\circ} \mathrm{C} / 45$ minutes on antibiotic residues.

\section{Detection of antibiotic residues: Direct method}

The direct detection of antibiotic residues was carried out following a previously published technique (29). Briefly, a disc-shaped meat sample of $8 \mathrm{~mm}$ in diameter and $2 \mathrm{~mm}$ thick was prepared and placed on the surface of MullerHinton (MH) agar (HiMedia, India), pre-inoculated by spore suspension of a susceptible strain of Bacillus subtilus (0.1 $\mathrm{ml} / 100 \mathrm{ml}$ medium). Bacillus subtilis suspension was prepared at preferred concentration according to standard methods $(30,31)$. Plates were incubated aerobically at $37^{\circ} \mathrm{C}$ for $24 \mathrm{hrs}$. After incubation, diameters of inhibition zones around meat disks were measured in $\mathrm{mm}$. Zone equal or more than to $2 \mathrm{~mm}$ was considered as a positive result. While zones smaller than $1 \mathrm{~mm}$ was considered as negative results. 
If no zone appeared in the control sample, plates were selected for evaluation.

\section{Detection of antibiotic residues: Extraction method}

The technique cited by Al- Rubeae (30) was adopted. Briefly, twenty $\mathrm{ml}$ of potassium phosphate solution were added to $10 \mathrm{~g}$ of meat sample. After centrifugation at 4000 $\mathrm{rpm}$ for 10 minutes, $0.2 \mathrm{ml}$ of the supernatant was delivered into wells on pre-inoculated $\mathrm{MH}$ agar and incubated at $37^{\circ} \mathrm{C}$ for 20-24 hours.

\section{Effect of thermal processing methods on positive samples}

Chilling: Meat samples which showed positive results in the extraction methods were preserved in cooling at $4{ }^{\circ} \mathrm{C}$. After 3 days, samples were inspected for the continuity of antibiotic residues by the extraction methods.

Freezing: Samples which showed positive results in the extraction methods were saved in a freezer at $-18^{\circ} \mathrm{C}$. After 6 weeks, antibiotic residues existence was estimated by the extraction methods.

Thermal processing (cooking): Nearly 50 grams of each positive sample were placed into a strainer and soaked in 250 $\mathrm{ml}$ of water bath preheated to $100{ }^{\circ} \mathrm{C}$ for 45 minutes. Samples then removed from water and allowed to cool before re-assessment for antibiotic residues by extraction method.

\section{Statistical analysis}

All data were analyzed by SPSS version 21.00; chisquare test was employed to assess the difference between samples and methods. Confidence intervals were calculated by normal approximation method. Association between seasons and antibiotic residues was analyzed by Fisher's exact test. $\mathrm{P}$ value less than 0.05 was considered significant.

\section{Results}

\section{Incidence of antibiotic residues}

Out of 280 raw sheep meat samples, positive samples comprised $10.4 \%(29 / 280)$ and $13.2 \%$ (37/280) when tested by direct and extraction methods respectively (Table 1). Statistically, it is estimated that $6.79 \%-13.93 \%(95 \%$ confidence interval) of raw sheep meat in Erbil market is contaminated by antibiotic residues if tested by the direct method. While $9.25-17.18 \%$ of sheep meat is expected to harbor antibiotic residues if tested by the extraction method. There is no significant difference between the two methods used for residues screening $(P=0.305)$.

\section{Changes in rates of antibiotic residues during study period}

The change in incidence rate of antibiotic residues was observed through study period. The highest rate of residues was detected in late winter, while the lowest rate was found in July and August (6.7\%). Table 2 summarizes the detection rates in temporal scale. There is no significant difference between seasons (winter and autumn) in terms of incidence of antibiotic residues among sheep meat $(P=0.091)$. In general, the incidence of residues in sheep meat increased as summer and autumn progress $\left(\mathrm{R}^{2}=0.74\right)$.

\section{Effect of preservative methods on persistence of antibiotics residues}

The effectiveness of chilling at $4{ }^{\circ} \mathrm{C}$ for 3 days on the incidence of antibiotic residues among positive sheep meat samples was low. In fact, only $16.2 \%$ of residues-positive samples showed clearance of the residues after cooling (Table 3). In contrast, freezing at $-18{ }^{\circ} \mathrm{C}$ for six weeks was even less effective than chilling on the incidence of antibiotic residues (Table 3). However, there is no significant difference between the preservative methods $(P=0.746)$. Lastly, heat processing at $100{ }^{\circ} \mathrm{C}$ for 45 minutes showed complete $100 \%$ deactivation of antibiotic residues against challenged bacteria.

\section{Discussion}

The administration of antibiotic drugs in animal farming is prevalent and often indispensable. Indeed, rearing of large number of animals in small spaces facilities transmission of various infectious diseases. In crowded farms, bacterial infections are common and require a continuous input of antibiotics for therapeutic and prophylactic purposes. However, antibiotic residues settle in animal's tissues for different periods of time. Not only meat and other tissues harbor the antibiotic residues, but also, they can be found in milk or other dairy products from treated animals $(12,32)$.

Lamb meat is characterized by its notable nutritional value. On the other hand, mutton meat has a higher fat content and strong flavor $(33,34)$. Recently, antibacterial residues in food of animal origin have become a concern with extensive lack of certainty about the hazards caused by antibacterial residues to consumers. One of these hazards is the continuous selection of bacterial resistant strains. Indeed, the World Health Organization (WHO) announced that antibacterial resistance is an intercontinental problem that requires effective and rapid countermeasures to diminish the increasing level of resistant bacterial species. Moreover, Abd Al-Zahra and Ahmed (35), recommends that the obtained milk or meat from food producing animals treated with veterinary medicines/drugs must not contain any residue.

In the present work, the incidence rate of antibiotic residues in total sheep meat samples according to direct method was $10.4 \%$. On the other hand, the incidence rate according to extraction method was $13.2 \%$ (Table 1). These findings are consistent with an Iranian study which found an incidence rate of $14.0 \%$ in mutton (36). In contrast, lower incidence rates 6.00 and $8.3 \%$ were reported in sheep meat 
samples analyzed in Yemen and Spain respectively $(29,37)$. On the contrary, higher rates have been reported previously from different countries. For instance, in Nigeria, antibiotic residues were presented in $44 \%$ of the slaughtered cattle
(38). Additionally, higher rates were reported from Turkey $57.7 \%$ (39), Ethiopia $71.3 \%$ to $82 \%$ (40,41). Such variations may be attributed to the difference in antibiotic usage practice in animal farming.

Table1: Incidence of antibiotic residues among sheep meat samples

\begin{tabular}{lccccc}
\hline \multirow{2}{*}{ Meat } & No. & \multicolumn{2}{c}{ Direct method } & \multicolumn{2}{c}{ Extraction method } \\
\cline { 3 - 6 } & Tested & Positive n $(\%)$ & Negative n (\%) & Positive n (\%) & Negative n (\%) \\
\hline Lamb & 135 & $13(9.6)$ & $122(90.4)$ & $15(11.1)$ & $120(88.9)$ \\
Mutton & 145 & $16(11.1)$ & $129(88.9)$ & $22(15.2)$ & $123(84.8)$ \\
\hline Total & 280 & $29(10.4)$ & $251(89.6)$ & $37(13.2)$ & $243(86.8)$ \\
\hline
\end{tabular}

Table 2: Temporal distribution of antibiotic residues in sheep meat by extraction method

\begin{tabular}{|c|c|c|c|c|c|c|}
\hline \multirow{2}{*}{ Month } & \multicolumn{2}{|c|}{ Lamb } & \multicolumn{2}{|c|}{ Mutton } & \multirow[b]{2}{*}{ Total examined } & \multirow[b]{2}{*}{ Total positive (\%) } \\
\hline & No. examined & No. Positive & No. examined & No. Positive & & \\
\hline July & 22 & 1 & 23 & 2 & 45 & $3(6.7)$ \\
\hline August & 22 & 1 & 23 & 2 & 45 & $3(6.7)$ \\
\hline September & 23 & 2 & 26 & 3 & 49 & $5(10.2)$ \\
\hline October & 23 & 3 & 26 & 5 & 49 & $8(16.3)$ \\
\hline November & 23 & 4 & 24 & 4 & 47 & $8(17.0)$ \\
\hline December & 22 & 4 & 23 & 6 & 45 & $10(22.2)$ \\
\hline Total & 135 & 15 & 145 & 22 & 280 & $37(13.2)$ \\
\hline
\end{tabular}

Table 3. Effect of chilling \& freezing on antibiotic residues persistence by extraction method

\begin{tabular}{lcccc}
\hline Types of samples & $\begin{array}{c}\text { No. of positive samples } \\
\text { before chilling }\end{array}$ & $\begin{array}{c}\text { No. of affected sample } \\
\text { after chilling }(\%)\end{array}$ & $\begin{array}{c}\text { No. of positive samples } \\
\text { before freezing }\end{array}$ & $\begin{array}{c}\text { No. of affected sample } \\
\text { after freezing }(\%)\end{array}$ \\
\hline Lamb & 15 & $4(26.7)$ & 15 & $3(20.0)$ \\
Mutton & 22 & $2(9.1)$ & 22 & $2(9.1)$ \\
\hline Total & 37 & $6(16.2)$ & 37 & $5(13.5)$ \\
\hline
\end{tabular}

Humidity of normal pasture in winter may lead to increase in diseases incidence rates which requires intervention practices involving antibiotics. In terms of seasonal variations of residues level, this work is in good agreement with an Iranian study reporting the highest contamination rate of milk with antibacterial residues occurred in winter and ranged from $44.5 \%$ to $65.9 \%$. In fact, it has been confirmed that winter season is correlated with increased rate of antibacterial residues in poultry meat samples examined in Yemen and recently in Iraq $(10,29)$.

The chilling and freezing methods created approximately comparable effects on reduction of antibiotic residues in sheep meat. There is a shortage of information on the precise effect of chilling and freezing in determining the fate of antibacterial residues in sheep meat. On the other hand, thermally-processed samples at $100^{\circ} \mathrm{C}$ for 45 minutes revealed total reduction in activity of antibiotic residues against test bacteria. These findings are compatible with an Egyptian study (42) which reported that antibacterial potentials disappeared in the cooked meat samples previously harbored antibiotic residues. This is mostly attributed to the destructive effects of thermal processing. The application of various cooking methods; boiling, frying, and grilling of meat revealed significant reduction rates in concentration of residues that ranged from $81.22 \%$ by boiling for penicillin to $96.58 \%$ by grilling for oxytetracycline (18). These findings are further supported by a recent study (19) that found the reduction rate of oxytetracycline residues in beef with boiling up to $87.8 \%$ in 30 minutes and barbecued meat up to $90.9 \%$ in 20 minutes. Such slight differences are possibly resulted from various degrees of applied heat, type of antibiotic, or even the kind of meat per se. In the present work, the findings of boiling effect are in good agreement with the aforementioned reports. Moreover, microwaving and roasting were found to significantly reduce the inhibition zones produced by raw liver sample (17). 


\section{Conclusion}

Findings from this study have shown that lamb meat and mutton harbor antibiotic residues in levels higher than accepted. Chilling and freezing slightly decrease the antibacterial residues in lamb meat and mutton but thermal processing successfully deactivated antibiotic residues. However, the in vivo fates of heat-degraded residues are unclear. The potential harm and their interactions worth studying with particular focus on the toxicological scope. Additionally, accurate analytical and screening methods in meat industry should be encouraged. Government authorities and regulatory bodies should implement the required restrictions on antibiotic utilization in animal farming.

\section{Acknowledgement}

Author wish to thank Knowledge University for supporting and providing facilities.

\section{References}

1. Singh BP, Rateb ME, Rodriguez-Couto S, Polizeli MLT, Li WJ. Editorial: Microbial Secondary Metabolites: Recent Developments and Technological Challenges. Frontiers in Microbiolog , 2019,Volume 10 | Article 914. doi: 10.3389/fmicb.2019.00914.

2. Ben Y, Fu C, Hu M, Liu L, Wong MH, Zheng C. Human health risk assessment of antibiotic resistance associated with antibiotic residues in the environment: A review. Env Res. 2018;169:483-493. DOI: 10.1016/j.envres.2018.11.040

3. Sarker YA, Hasan MM, Paul TK, Rashid SZ, Alam MN, Sikder MH. Screening of antibiotic residues in chicken meat in Bangladesh by thin layer chromatography. J Adv Vet Anim Res. 2018; 5:140-145. http://doi.org/10.5455/javar.2018.e257.

4. Polidori P, Ortenzi A, Vincenzetti S, Beghelli D. Dietary properties of lamb meat and human health. Mediterr J Nutr Metab (2011) 4:53-56. DOI 10.1007/s12349-010-0032-9.

5. Wyness $\mathrm{L}$. The role of red meat in the diet: nutrition and health benefits. Conference on 'The future of animal products in the human diet: health and environmental concerns' Symposium 1: Meat, health and sustainability. Proceedings of the Nutrition Society, 2015,Page 1 of 6 . doi:10.1017/S0029665115004267.

6. Ivanović S, Pavlović I, Pisinov B. The Quality of Goat Meat and its Impac on Human Health. Biotechnology in Animal Husbandry 32 (2), p 111-122, 2016. DOI: 10.2298/BAH1602111I.

7. Beyene $T$. Veterinary drug residues in food-animal products: its risk factors and potential effects on public health. J Vet Sci Technol. 2016;7:1-7. http://dx.doi.org/10.4172/2157-7579.1000285.

8. Tang KL, Caffrey NP, Nóbrega DB, Cork SC, Ronksley PE, Barkema HW, Polachek AJ, Ganshorn H, Sharma N, Kellner JD, Ghali WA. Restricting the use of antibiotics in food-producing animals and its associations with antibiotic resistance in food-producing animals and human beings: a systematic review and meta-analysis. Lancet Planet Health. 2017;1:e316-327. DOI:https://doi.org/10.1016/S25425196(17)30141-9

9. Ahangaran MG, Peimani N ,Dastgerdi AA. The effect of thyme (Thymus daenensis) supplement on growth and hygienic parameters of broilers meat. Iraqi J Vet. Sci., Vol. 33, No. 1, 2019 (8792).10.33899/ijvs.2019.125526.1048.

10. Al-Mashhadany DA, Nahla AA, Zaki AM, Mohammad VS. Detection of antibiotic residues among poultry meat in Erbil city and impact of thermal processing on remnants. Res J Life Sci Bioinform Pharm Chem Sci. 2018;3:237-247. DOI - 10.26479/2018.0401.19.

11. Ortelli D, Spörri AS, Edder P. veterinary drug residue in food of animal origin in Switzerland: a health concern?. CHIMIA Int J Chem.2018;72:713-717. https://doi.org/10.2533/chimia.2018.713

12. Rossi R, Saluti G, Moretti S, Diamanti I, Giusepponi D, Galarini R.(2018): Multiclass methods for the analysis of antibiotic residues in milk by liquid chromatography coupled to mass spectrometry: a review. Food additives and contaminants. Food Addit Contam Part A Chem Anal Control Expo Risk Assess 2018; 35(2):242-57; https://doi. org/10.1080/19440049.2017.1393107.

13. Jayalakshmi K, Paramasivam M, Sasikala M, Tamilam TV, Sumithra A. Review on antibiotic residues in animal products and its impact on environments and human health. J Entomol Zool Stud. 2017;5:14461451

14. Regea G. Review on antibiotics resistance and its economic impacts. J Pharmacol Clin Res. 2018;5:555675. DOI: 10.19080/JPCR.2018.05.555675

15. Li JH, Yousif MH, Li ZQ, Wu ZH, Li SL, Yang HJ, Wang YJ, Cao ZJ. Effects of antibiotic residues in milk on growth, ruminal fermentation, and microbial community of preweaning dairy calves. J Dairy Sci. 2019;102:2298-307. doi: 10.3168/jds.2018-15506.

16. Nasef,I.O., El-Leboudy,A.A., Amer,A.A. and El-Ansary,M.A.(2019): Monitoring of some pesticides residues in raw milk in Alexandria province, Egypt. AJVS 60 (1): 196-203. DOI: 10.5455/ajvs.1373.

17. Vivienne EE. Occurrence of antimicrobial residues in Broilers in Enugu Metropolis and the effect of temperature on the concentration of oxytetracycline residue. Nsukka,. Faculty of Veterinary Medicine University of Nsukka. Nigeria. 2014.

18. Elbagory AM, Yasin NA, Algazar EA. Effect of various cooking methods on some antibacterial residues in imported and local frozen dressed broilers and their giblets in Egypt. Nutr Food Technol. 2016;16. http://dx.doi.org/10.16966/2470-6086.127.

19. Mgonja F, Mosha R, Mabiki F, Choongo K. Effect of heat treatment on oxytetracycline residues in beef. Am J Res Commun. 2017;5:1-13.

20. Islas G, Rodriguez JA, Perez-Silva I, Miranda JM, Ibarra IS. Solidphase extraction and large-volume sample stacking-capillary electrophoresis for determination of tetracycline residues in milk. J Anal Methods Chem. 2018. ; Article ID 5394527, 7 pages. doi: $10.1155 / 2018 / 5394527$

21. Al-Mashhadany DA. Detection of antibiotic residues among raw beef in Erbil city (Iraq) and impact of temperature on antibiotic remains. Italian J Food Safety. 2019;8,1-19. doi: 10.4081/ijfs.2019.7897

22. Liu M, Wang Z, Li X, Chu X, Dong Y, Zhang Y. Application of the mechanical high-pressure method combined with high-performance liquid chromatography-tandem mass spectrometry for determination of veterinary drug residues in incurred chicken and rabbit muscle tissues. J Food Prod. 2019;82:415-421. https://doi.org/10.4315/0362028X.JFP-18-386

23. Santos L, Rosa J, Freitas A, Leston S, Barbosa J, Ramos F. Detection and quantification of 47 antibiotic residues in farmed European sea bass (Dicentrarchus labrax) using a multi-class and multi-residue UHPLCMS/MS method. Food Addit Contam. 2019;4:561-570. doi: $10.1080 / 19440049.2019 .1572229$

24. Soepranianondo K, Wardhana DK, Budiarto D. Analysis of bacterial contamination and antibiotic residue of beef meat from city slaughterhouses in East Java Province, Indonesia, Vet World. 2019;12: 243-248. doi: 10.14202/vetworld.2019.243-248.

25. Rana, Md.S. , Lee, S.Y. , Kang,H.J. and Hur,S.J.(2019): Reducing Veterinary Drug Residues in Animal Products: A Review. Food Sci. Anim. Resour. 2019 October 39(5):687 - 703. DOI https://doi.org/10.5851/kosfa.2019.e65.

26. Manyi-Loh C, Mamphweli S, Meyer E, Okoh A. Antibiotic use in agriculture and its consequential resistance in environmental sources: potential public health implications. Molecules. 2018 Mar 30;23(4):795. doi: 10.3390/molecules23040795. 
27. Kebede G, Zenebe T, Disassa H, Tolosa T. Review on detection of antimicrobial residues in raw bulk milk in dairy farms. Afr J Basic Appl Sci 2014; 6(4):87-97. DOI: 10.5829/idosi.ajbas.2014.6.4.8642.

28. Delatour T, Racault L, Bessaire T, Desmarchelier A. Screening of veterinary drug residues in food by LC-MS/MS. Background and challenges. Food Addit Cont. 2018;35:632-645. doi: 10.1080/19440049.2018.1426890.

29. Al-Mashhadany DA. Detection of antibiotic residues in red meat and the effect of heat treatment on them. Thamar Uno J Stud Res. 2009;1:17-28.

30. Hussein AEY, Elmansoury YH, Hussien MO, Taha MI, Mahgoub HA, El Hussein AM. Oxytetracycline residues in Sheep meat in Khartoum State, Sudan. J. Adv. Vet. Anim. Res., 2(3): 321-325. DOI: 10.5455/javar.2015.b101.

31. El Atabani AI, El-Ghareeb WR, Elabbasy MT, Ghazaly EI. Oxytetracycline residues in marketed frozen beef livers at Sharkia, Egypt. Benha Vet Med J. 2014;26:104-12.

32. Shang N, Chaplot S, Wu J. Food proteins for health and nutrition. In Yada RY editor. Proteins in food processing. Vancouver: Woodhead Publishing; 2017. 301-336 p. doi: 10.1016/B978-0-08-1007228.00013-9

33. Bohrer BM. Nutrient density and nutritional value of meat products and non-meat foods high in protein. Trend Food Sci Technol. 2017;65:103112. https://doi.org/10.1016/j.tifs.2017.04.016

34. Pethick, D.; Hopkins, D.; D’Souza, D.; Thompson, J.; Walker, P. E_ects of animal age on the eating quality of sheep meat. Aust. J. Exp. Agric. 2005, 45(5) 491-498 https://doi.org/10.1071/EA03256.
35. Abd Al-Zahra SA and Ahmed AJ. Impacts of processing heat treatments on deltmethrin and bifenthrin residues in human breast milk and raw milk from different animals. Iraqi J Vet. Sci.,2018:32:27-31. DOI: 10.33899/ijvs.2018.153790

36. Babapour A, Azami L, Fartashmehr J. Overview of antibiotic residues in beef and mutton in Ardebil, North West of Iran. World Appl Sci J. 2012;19:1417-22.

37. Sanz D, Razquin P, Condón S, Juan Esteban T, Herraiz B, Mata L. Incidence of antimicrobial residues in meat using a broad-spectrum screening strategy. European J Nutr Food Saf. 2015;5:156-165. https://doi.org/10.9734/EJNFS/2015/13795

38. Ibrahim AI, Junaidu AU, Garba MK. Multiple antibiotic residues in meat from slaughtered cattle in Nigeria. Inter J Vet Med. 2010;8:1-5.

39. Er B, Onurdağ FK, Demirhan B, Özgacar SÖ, Öktem AB, Abbasoğlu $\mathrm{U}$. Screening of quinolone antibiotic residues in chicken meat and beef sold in the markets of Ankara, Turkey. Poult Sci. 2013;92:2212-5. doi: 10.3382/ps.2013-03072.

40. Bedada AH, Zewde BM, Zewde BM. Tetracycline residue levels in slaughtered beef cattle from three slaughterhouses in central Ethiopia. Glob Vet. 2012;8:546-554

41. Agmas B, Adugna M. Antimicrobial residue occurrence and its public health risk of beef meat in Debre Tabor and Bahir Dar, Northwest Ethiopia. Vet World. 2018;11:902-908. DOI: 10.14202/vetworld.2018.902-908.

42. El-Wehedy SE, Darwish WS, Tharwat AE, Hafez AE. Estimation and health risk assessment of toxic metals and antibiotic residues in meats served at hospitals in Egypt. J Vet Sci Technol. 2018;9. doi: $10.4172 / 2157-7579.1000524$. 